\title{
USING SOME BIOCHEMICAL TREATMENTS TO IMPROVE NUTRITIVE VALUE OF SOME POOR QUALITY ROUGHAGES (IN VITRO AND IN VIVO STUDIES)
}

\author{
R. Salama , A.A. Awad and Sh.M. Fouda \\ Animal Production Department, Faculty of Agriculture, Al-Azhar University, Naser city, Cairo, Egypt.
}

(Received 5/6/2019, accepted 22/7/2019)

\section{SUMMARY}

$\mathrm{T}$ he objective of the present study was to evaluate the effect of some biochemical treatments on the chemical composition in vitro, in vivo digestibility and nutritive values of some poor quality roughages, i.e. sugar cane bagasse $(\mathrm{SCB})$ and corn cobs $(\mathrm{Ccb})$. The experimental treatments were either 3 liter ZAD compound (Liquor) or $5 \mathrm{~kg}$ ZADO powder compound (a biotechnical powder product made from natural sources of cellulose enzyme from anaerobic bacteria) added to 500 litter water $+50 \mathrm{~kg}$ molasses and $20 \mathrm{~kg}$ urea / ton roughages. Sugar cane bagasse (SCB) and corn cobs (Ccb) treated with biological treatments (ZAD and/or ZADO compounds) and/or chemical treatment (urea) were ensiled for 30 days (In vitro). Five biochemical treatments for both of the two tested roughages were conducted as follows; Untreated SCB or Ccb and served as a control (T1 \& T6), SCB or Ccb treated with 3 litter ZAD compound (liquor)/ton $+5 \%$ molasses (T2 \& T7), SCB or Ccb treated with 3 litter ZAD compound (liquor)/ton $+2 \%$ urea $+5 \%$ molasses (T3\&T8), SCB or Ccb treated with 3 litter ZAD compound (liquor)/ton $+5 \mathrm{~kg}$ ZADO compound (Powder)/ton $+5 \%$ molasses $(\mathrm{T} 4 \& \mathrm{~T} 9)$, SCB or Ccb treated with 3 litter ZAD compound (liquor)/ton $+5 \mathrm{~kg}$ ZADO compound (Powder)/ton $+2 \%$ urea $+5 \%$ molasses (T5 \& T10). On the light of in vitro results, 10 complete mixed rations, consisted of $75 \%$ concentrate feed mixture (CFM, $14 \% \mathrm{CP}$ ) and $25 \%$ untreated roughage (control) or ensiled treated ones were used in a digestibility trail (In vivo). Results obtained showed that: ensiling untreated roughages $(\mathrm{SCB} \& \mathrm{Ccb}$ ) for 30 days incubation period with ZAD and ZADO compounds led to increase $(\mathrm{P}<0.05) \mathrm{DM}, \mathrm{OM}, \mathrm{CP}$ and NFE and decreased $(\mathrm{P}<0.05) \mathrm{CF}$ and ash contents and led to an obvious improvement in their fiber fractions; i.e. decreased $(\mathrm{P}<0.05) \mathrm{NDF}, \mathrm{ADF}, \mathrm{ADL}$, acid ash and hemicellulose, and showed insignificant effect on both of cellulose and lignin contents for both the two treated materials. However, variable significant responses were evident in the changes occurred in fiber fractions for both the two treated roughages. Adding ZAD and ZADO compounds to untreated roughages led to improve $(\mathrm{P}<0.05)$ nutrients coefficients digestibility and nutritive values in compare with the untreated materials. However, both the two complete mixed rations indicated similar TDN, SE and DCP values i.e. $60.75 \%$ and $62.57 \%, 56.55 \%$ and $58.16 \%$ and $9.48 \%$ vs. $9.28 \%$ for both of SCB and Ccb rations, respectively. On the light of the present results, it could be concluded that, treating poor quality roughages (SCB \& Ccb) with the natural biological additives (probiotics ZAD \& ZADO compounds) led to improve roughage chemical composition, digestibility of their nutrients, roughage palatability and in turn might contribute to the marginal field of available roughage resources.

Keywords: Sugar cane bagasse, corn cobs, ZAD and ZADO, biochemical and probiotics.

\section{INTRODUCTION}

Low quality roughages are inefficiently utilized by ruminants. This is due to low digestibility and poor nutritive value associated particularly with cereal straw. These materials supply no more energy than poor quality hay, TDN is less than 50\% and starch value (SV) is less than 29\% (Balch, 1976).

In Egypt about 610.000 tons of corn cobs (Ccb) are wasted yearly, which equal about 146.40 tons starch value and 32000 tons crude protein (EL-Khimsawy, 1990). Sugar cane bagasse (SCB) is a secondary byproduct of sugar cane extraction factories. Bagasse represents 30-32 \% of the sugar cane plant (Barnes, 1980). The annual production of SCB in Egypt is in the order of one million metric tons / year (Ministry of Agriculture, 1996 and 2000). There is a possibility of using bagasse in livestock feeding. During the past 


\section{Salama et al.}

century, continuous efforts had been made to improve the efficiency of utilization of the lignoceellulose crop residues through physical, chemical and biological treatments.

Enzymes have been also used in ruminant rations to degrade fiber contents, to make it more easier for digestion, to be more useful for the micro-organisms and flora which are the main source of the microbial protein in the ruminal media and to reduce the costs of the ration. Colombatto et al., (2003) reported that enzymes were more efficient in degrading fibers without increasing methane production in the rumen of the animal. It is well known that some microorganisms, including ZAD and ZADO compounds (probiotics), can degrade lignin in the cell walls, and attempts had been made to improve digestibility of plant residues by adding ZAD and ZADO compounds (Gado, 1997; Gado, et al., 2013 ) to ruminant rations.

The objective of the present study was to evaluate the effect of some chemical treatments; using urea and biological treatments (ZAD and ZADO compounds) to improve chemical composition and nutritive value of some poor quality roughages i.e. sugar can bagasse (SCB) and ground corn cobs (Ccb) as ruminant feeds.

\section{MATERIALS AND METHODS}

The present study was carried out in the experimental farm station belongs to faculty of Agriculture, Animal Prod. Department, Al-Azhar University, Nasr City, Cairo, Egypt through the period from September 2017 to January 2018.

\section{Biological treatment:}

ZAD (patent on: 22155) is a bio-technical product made from natural sources to justify the level of cellulase enzymes from anaerobic bacteria, which can convert the polysaccharide into monosaccharide by specific enzymes, such as cellulase $8.2 \mathrm{u} / \mathrm{gm}$ and hemicellulase $6.2 \mathrm{u} / \mathrm{gm}$, in addition of activated amylase $64.4 \mathrm{u} / \mathrm{mg}$ and protease $12.3 \mathrm{u} / \mathrm{gm}$, (Gado et al., 2006 and Rmadan, 2007 ). ZADO compound is similar to ZAD, but the former one enzymes are much higher per gm fed and its anaerobic nature are found in hyperanation phase. ZAD and ZADO components are presented in Table (1). ZAD is live anaerobic bacteria with their enzymes, while, ZADO is a coated material of enzymes and bacteria.

Table (1): Enzymes concentration in ZAD and ZADO used in the experiment.

\begin{tabular}{ccccc}
\hline Sample & Xylanase & $\alpha$-amylase & Cellulase & Protease \\
\hline ZAD (U/g) & 6.93 & 64.4 & 8.2 & 12.3 \\
ZADO & $.058 \mathrm{U} / \mathrm{g}$ & $3.39 \mathrm{U} / \mathrm{ml}$ & $.892 \mathrm{U} / \mathrm{ml}$ & $1.56 \mathrm{U} / \mathrm{ml}$ \\
\hline
\end{tabular}

Crop residues preparation: Two different types of low quality roughages were used i.e. sugar can bagasse (SCB) and ground corn cobs $(\mathrm{Ccb})$, which were chopped or crushed to 1-3 and 0.5 cm, respectively. Control sample of each SCB and Ccb were sun dried to approximately $95 \%$ dry matter. The experimental samples were composted with 3 litter ZAD compound (liquor) and $5 \mathrm{~kg}$ ZADO compound (Powder) to 500-litter water for 1 ton SCB or ground $(\mathrm{Ccb})$.

\section{Laboratory treatments (In Vitro):}

Each of SCB and Ccb roughage was distributed into 5 treatments as follows:-

1- Untreated SCB and served as a control (T1).

2-SCB treated with 3 litter ZAD compound (liquor)/ton $+5 \%$ molasses (T2).

3- SCB treated with 3 litter ZAD compound (liquor)/ton $+2 \%$ urea $+5 \%$ molasses (T3).

4- SCB treated with 3 litter ZAD compound (liquor)/ton + $5 \mathrm{~kg}$ ZADO compound (Powder)/ton $+5 \%$ molasses (T4).

5- SCB treated with 3 litter ZAD compound (liquor)/ton $+5 \mathrm{~kg}$ ZADO compound (Powder)/ton $+2 \%$ urea $+5 \%$ molasses (T5)

6- Untreated Ccb and served as a control (T1).

7- Ccb treated with 3 litter ZAD compound (liquor)/ton+ 5\% molasses (T2). 
8- $\mathrm{Ccb}$ treated with 3 litter ZAD compound (liquor)/ton $+2 \%$ urea $+5 \%$ molasses (T3).

9- Ccb treated with 3 litter ZAD compound (liquor)/ton + $5 \mathrm{~kg}$ ZADO compound (Powder)/ton; + 5\% molasses (T4).

10- $\mathrm{Ccb}$ treated with 3 litter ZAD compound (liquor)/ton $+5 \mathrm{~kg}$ ZADO compound (Powder)/ton $+2 \%$ urea $+5 \%$ molasses (T5).

Treated materials were incubated for three different periods, (10, 20 and 30 days).

\section{Chemical and biological treatment parameters:}

1-Proximate chemical analysis.

2-Fiber fractions (NDF, ADF, ADL, hemicellulose, cellulose and lignin ).

\section{Digestibility trials:}

Forty adult Ossimi rams were divided into ten similar groups and used to carry out ten metabolic trials, using four animals / each group, according to El-shazly et al. (1963).

Experimental rations consisted of $75 \%$ concentrate feed mixture (CFM, 14\% CP) and $25 \%$ (SCB) or ground (Ccb) .Experimental animals were fed CFM $(14 \% \mathrm{CP})$ to cover their maintenance requirement (N.R.C., 1989). The chemical composition and fiber fractions of CFM (on DM basis\%) during the digestibility trial are shown in Table (2).

Table (2): Chemical composition of CFM (\% on dry matter basis) .

\begin{tabular}{ccccccccccc}
\hline Item & DM & OM & CP & CF & EE & Ash & NFE & NDF & ADF & ADL \\
\hline CFM & 90.67 & 90.27 & 14.16 & 11.1 & 4.07 & 9.73 & 60.94 & 46.06 & 22.33 & 11.42 \\
\hline
\end{tabular}

\section{Proximate chemical analysis:}

Proximate chemical analysis of untreated and biochemically treated sugar cane bagasse, ground corn cobs and feces were done according to the standard procedures of A.O.A.C. (2005). Cell wall constituents of untreated and biochemically treated sugar cane bagasse and ground corn cobs were determined according to Goering and Van Soest (1982).

\section{Statistical analysis:}

Data were analyzed using the general linear models procedure adopted by SAS (1996). Differences among means were tested for significancy by Duncan's multiple range test (Duncan, 1955). Analysis of variance with repeated measurements and least square means were carried out using the following equation:

$$
\mathrm{Y}_{\mathrm{ij}}=\mu+\mathrm{T}_{\mathrm{i}}+\mathrm{R}_{\mathrm{J}}+\mathrm{E}_{\mathrm{i} J}
$$

Where:

$\mathrm{Y}_{\mathrm{IJ}}=$ the observation of the parameter measured.

$\mu=$ overall means.

$\mathrm{T}_{\mathrm{i}}=$ the effect of dietary treatment.

$\mathrm{R}_{\mathrm{j}}=$ the effect of replication.

$\mathrm{E}_{\mathrm{iJ}}=$ the random error term.

\section{RESULTS AND DISCUSSION}

Data presentd in Table (3) showed the effect of ZAD and ZADO compounds on the changes occurred in the chemical composition of both of SCB and $\mathrm{Ccb}$ at different incubation periods i.e. after 10, 20 and 30 days, respectively . 


\section{Salama et al.}

Chemical composition of both the two untreated roughages at 0 time i.e. before treatments, indicated higher DM, CF, EE and ash contents for SCB, but lower OM, CP and NFE contents in compare with untreated $(\mathrm{Ccb})$ material.

After 10 days incubation period, it was noticed higher $(\mathrm{P}<0.05) \mathrm{DM}$, CF and ash contents for treated $\mathrm{SCB}$, but lower $(\mathrm{P}<0.05) \mathrm{OM}, \mathrm{CP}$ and NFE contents, with almost similar EE percentages.

The lower OM content of SCB before and after 20 days incubation period and the higher $(\mathrm{P}<0.05)$ corresponding one for treated $\mathrm{Ccb}$ may be related to the higher ash content in treated SCB. However, ash content for both the two treated roughages tended to decrease due to biological and/or biochemical treatments.

It was also of interest to note that, although $\mathrm{CP}$ and NFE tended to be increased due to different applicable treatments; CF, EE and ash contents tended to be decreased. However, EE still maintaining almost similar insignificant values after 20 days incubation period. It was also worthy to note that nutrients of both the two treated roughages responded relatively to different biological and/or biochemical treatments. More pronounced changes were detected in treated SCB rather than the corresponding treated Ccb i.e. higher decrease in both of EE and ash contents.

Table (3): Mean of changes in chemical composition of treated sugar cane bagasse and corn cobs with ZAD and ZADO compounds after 10, 20 and 30 days incubation periods.

\begin{tabular}{|c|c|c|c|c|c|c|c|c|}
\hline $\begin{array}{l}\text { Incubation periods } \\
\text { (days) }\end{array}$ & Item & DM & $\mathrm{OM}$ & $\mathrm{CP}$ & $\mathrm{CF}$ & $\mathrm{EE}$ & Ash & NFE \\
\hline \multirow{2}{*}{0} & $\begin{array}{l}\text { Control } \\
\text { (SCB) }\end{array}$ & 94.95 & 94.25 & 2.49 & 53.89 & 3.01 & 5.75 & 34.86 \\
\hline & $\begin{array}{l}\text { Control } \\
\text { (Ccb) }\end{array}$ & 89.54 & 95.66 & 2.60 & 39.96 & 1.53 & 4.34 & 51.57 \\
\hline \multirow{2}{*}{10} & SCB & $95.20^{\mathrm{A}}$ & $96.60^{\mathrm{B}}$ & $2.72^{\mathrm{B}}$ & $52.77^{\mathrm{A}}$ & 1.36 & $3.33^{\mathrm{A}}$ & $39.80^{\mathrm{B}}$ \\
\hline & $\mathrm{Ccb}$ & $91.88^{\mathrm{B}}$ & $98.09^{\mathrm{A}}$ & $3.0^{\mathrm{A}}$ & $38.40^{\mathrm{B}}$ & 1.41 & $1.90^{\mathrm{B}}$ & $55.27^{\mathrm{A}}$ \\
\hline \multirow{2}{*}{20} & SCB & $96.03^{\mathrm{A}}$ & $96.58^{\mathrm{B}}$ & $2.72^{\mathrm{B}}$ & $51.17^{\mathrm{A}}$ & 1.31 & $4.41^{\mathrm{A}}$ & $41.37^{\mathrm{B}}$ \\
\hline & $\mathrm{Ccb}$ & $93.34^{\mathrm{B}}$ & $98.08^{\mathrm{A}}$ & $4.13^{\mathrm{A}}$ & $36.98^{\mathrm{B}}$ & 1.28 & $1.91^{\mathrm{B}}$ & $55.67^{\mathrm{A}}$ \\
\hline \multirow{2}{*}{30} & SCB & $97.39^{\mathrm{A}}$ & $96.54^{\mathrm{B}}$ & $4.31^{\mathrm{B}}$ & $49.48^{\mathrm{A}}$ & 1.26 & $3.45^{\mathrm{A}}$ & $41.47^{\mathrm{B}}$ \\
\hline & $\mathrm{Ccb}$ & $96.30^{\mathrm{B}}$ & $98.05^{\mathrm{A}}$ & $4.84^{\mathrm{A}}$ & $34.59^{\mathrm{B}}$ & 1.28 & $1.94^{\mathrm{B}}$ & $57.33^{\mathrm{A}}$ \\
\hline
\end{tabular}

$A \& B$ different capital letters in the same column indicated significant difference $(P<0.05)$.

After 20 days incubation period the similar trends in nutrients decrease and increase were also noticeable for both the two treated roughages with also relative responses to different applicable biological and/or biochemical treatments, with almost similar insignificant EE contents for both the two treated materials.

Changes in nutrients of both of treated SCB and $\mathrm{Ccb}$ after 30 days incubation period in percentage indicated 2\% increase in DM content or treated SCB vs. $7 \%$ for treated Ccb; similar increase in OM and CP contents $2.4 \%$ vs. $2.39 \%$ and $7.3 \%$ vs. $8.6 \%$ and $8 \%$ vs. $13 \%$ decrease in CF content, higher significant decrease in EE of SCB (58\%) vs. (16\%) for treated Ccb and (40\% vs. 55\%) decrease in ash contents with higher increase in NFE for treated SCB (18\% vs. 11\%) for treated Ccb, respectively . Such results confirmed the previous finding, as 1) nutrients of both the two treated roughages responded relatively to different biological and/or chemical treatments; 2) elongation of the incubation period for both the two treated roughages led to more significant improvement in the chemical composition of both the two treated roughages, although some of nutrients in both the two treated materials indicated either higher positive or negative changes due to the elongation of incubation period i.e. positive $\mathrm{CP}$ content $(7.3-8.6 \%)$, but negative $\mathrm{CF}, \mathrm{EE}$ and ash contents $(8-13 \%, \mathrm{CF}),(58-16 \%, \mathrm{EE})$ and $(40-50 \%$, ash) for both of treated $\mathrm{SCB}$ and $\mathrm{Ccb}$, respectively . 
It was also worthy to note variable differences in the chemical composition and/or nutrients percentages for both the two treated roughages either before or after chemical and/or biochemical treatments with ZAD and ZADO compounds, regardless of different applicable treatments .

It was obvious from data presented herein, that the main positive improvement was in the CP content which increased significantly in both the two treated materials with ZAD (liquor and Powder) compounds. Values of $\mathrm{CP}$ were linearly increased as the time of ensiling increased. The effects were mainly due to nitrogen content of the added ZAD compounds or urea (about $20 \mathrm{~kg} / \mathrm{ton}$ ) and microbial nitrogen content of the prolific bacteria in silage of the two tested roughages. It may be explained on the basis that bacterial growth (the increase in single cell protein) was on the expense of EE as an energy source which significantly decreased in an opposite direction to that of CP increment. Abd El-Aziz et al. (1997) found that the biological treatment of straw and other fibrous roughages resulted usually in a marked increase in their CP content when the treatment condition was appropriate. Also, Dhanda et al. (1994) fermented wheat straw with white rot fungi sp. and noticed that $\mathrm{CP}$ content of the straw increased from 3.42 to $6.81 \%$, while Khorshed (2000) reported that biological treatments decreased $(\mathrm{P}<0.01)$ CF contents and increased $(\mathrm{P}<0.01)$ $\mathrm{CP}$ content of some crop residues.

Data presented in Table (4) showed the mean of changes in fiber fractions of treated SCB and Ccb with both of ZAD and ZADO compounds after different incubation periods, i.e. 10, 20 and 30 days , respectively. Data obtained at 0 time (before the biological treatments and ensiling), indicated similar NDF values, but higher ADF, ADL, cellulose and lignin for the untreated SCB with lower hemicellulose content in vice versa trend to untreated $(\mathrm{Ccb})$.

After 10 days of incubation with different ZAD and ZADO compounds; it was noticed, lower $(\mathrm{P}<0.05)$ decrease for both the two treated roughages in most of fiber fractions, except lignin which tended to increase slightly after 10 days incubation period . Bakshi et al., (1985) and Beauchemin et al., (1995) reported that the spent wheat straw by pleurotus sp. lowered CF, NDF, ADF, cellulose and hemicellulose content than untreated wheat straw. Also, Gado et al., (2006) reported a decrease in cell wall from $92.2 \%$ to $77.3 \%$ for untreated wheat straw (by white rot fungi), respectively.

Twenty days later, both the two treated roughages showed the same trend like that after 10 days incubation period, since different terms of fiber fractions tended to decrease $(\mathrm{P}<0.05)$ due to different applicable treatments, except lignin which continued to increase .

However, significant differences were detected between both the two treated roughages, due to the nature of its raw chemical structural and composition.

Table (4): Mean of changes in fiber fraction of treated SCB and Ccb with ZAD and ZADO compounds after 10, 20 and 30 days incubation periods.

\begin{tabular}{ccccccccc}
\hline $\begin{array}{c}\text { Incubation } \\
\text { periods } \\
\text { (days) }\end{array}$ & Item & NDF & ADF & ADL & $\begin{array}{c}\text { Acid } \\
\text { ash }\end{array}$ & $\begin{array}{c}\text { Hemic- } \\
\text { ellulose }\end{array}$ & Cellul-ose & Lignin \\
\hline \multirow{2}{*}{0} & $\begin{array}{c}\text { Control } \\
\text { (SCB) }\end{array}$ & 83.17 & 65.01 & 17.21 & 4.58 & 18.16 & 47.80 & 12.63 \\
& $\begin{array}{c}\text { Control } \\
(\text { Ccb) }\end{array}$ & 84.53 & 48.67 & 11.49 & 5.07 & 35.86 & 37.18 & 6.42 \\
& SCB & $82.41^{\mathrm{B}}$ & $64.27^{\mathrm{A}}$ & $17.12^{\mathrm{A}}$ & $3.49^{\mathrm{B}}$ & $18.14^{\mathrm{B}}$ & $47.14^{\mathrm{A}}$ & $13.62^{\mathrm{A}}$ \\
\multirow{2}{*}{10} & $\mathrm{Ccb}$ & $83.28^{\mathrm{A}}$ & $47.76^{\mathrm{B}}$ & $10.92^{\mathrm{B}}$ & $4.02^{\mathrm{A}}$ & $35.52^{\mathrm{A}}$ & $36.83^{\mathrm{B}}$ & $6.90^{\mathrm{B}}$ \\
& $\mathrm{SCB}$ & $81.30^{\mathrm{B}}$ & $63.57^{\mathrm{A}}$ & $17.08^{\mathrm{A}}$ & $3.42^{\mathrm{B}}$ & $17.72^{\mathrm{B}}$ & $46.50^{\mathrm{A}}$ & $13.65^{\mathrm{A}}$ \\
20 & $\mathrm{Ccb}$ & $81.66^{\mathrm{A}}$ & $47.38^{\mathrm{B}}$ & $10.47^{\mathrm{B}}$ & $3.76^{\mathrm{A}}$ & $34.28^{\mathrm{A}}$ & $36.91^{\mathrm{B}}$ & $6.71^{\mathrm{B}}$ \\
& $\mathrm{SCB}$ & $79.95^{\mathrm{B}}$ & $62.59^{\mathrm{A}}$ & $16.95^{\mathrm{A}}$ & $3.37^{\mathrm{B}}$ & $17.37^{\mathrm{B}}$ & $45.64^{\mathrm{A}}$ & $13.58^{\mathrm{A}}$ \\
30 & $\mathrm{Ccb}$ & $79.98^{\mathrm{A}}$ & $47.05^{\mathrm{B}}$ & $9.82^{\mathrm{B}}$ & $3.63^{\mathrm{A}}$ & $32.92^{\mathrm{A}}$ & $37.24^{\mathrm{B}}$ & $6.19^{\mathrm{B}}$ \\
\hline
\end{tabular}

$A \& B$ different capital letters in the same column indicated significant difference $(P<0.05)$.

After 30 days incubation, different terms of fiber fractions still maintained the lower $(\mathrm{P}<0.05)$ decrease including, the lignin content. It was of interest to note that; neither the decrease nor the increase in different 


\section{Salama et al.}

terms of fiber fractions was pronounced, but tended to have a slower visible rate either decrease or increase mechanism and regardless of the effect of incubation period and the effect of biological treatments, both of the two treated roughages continued to maintain its variable differences due to its nature of raw chemical structural and composition.

Elongation of ensiling and incubation period from 10 to 30 days, showed an effective role in the changes and improvement occurred in the chemical composition of both the two treated roughages, in spite of the slower changing rate.

After 30 days incubation period, treated SCB still maintained lower $(\mathrm{P}<0.05)$ NDF, acid ash and hemicellulose values, but higher $(\mathrm{P}<0.05) \mathrm{ADF}, \mathrm{ADL}$, cellulose and lignin contents, in compare with treated Ccb.

The decline in CF value in the tested roughages could be a result of the enzymes secreted by the growing prolific bacteria. El-Ashry et al. (2002) reported that cellulose contents of the silages were significantly reduced due to the biological treatments at the higher rate of enzymes. While, Mahrous and Abou Ammou (2005) showed that microbial treatments for rice straw increased CP contents significantly and decreased $\mathrm{CF}$, ash NDF, ADF, ADL and cellulose content than the control group.

\section{Digestibility coefficient and nutritive values of the different experimental rations:}

Data presented in Table (5) showed insignificant differences among different experimental groups in DMI. Dry matter intake of SCB ranged between $1181-1415 \mathrm{~g} / \mathrm{h} / \mathrm{d}$. The higher DMI was shown by both of (T2 and T3) i.e. 1338 and $1415 \mathrm{~g} / \mathrm{h} / \mathrm{d}$ for both groups, respectively. Dry matter intake of Ccb ranged between $1140-1436 \mathrm{~g} / \mathrm{h} / \mathrm{d}$. The higher DMI was shown by both of corn cobs treated with 3 litter ZAD compound (liquor)/ton $+5 \mathrm{~kg}$ ZADO compound (powder)/ton $+2 \%$ urea $+5 \%$ molasses and SCB treated with 3 litter $\mathrm{ZAD}$ compound (liquor)/ton $+2 \%$ urea $+5 \%$ molasses ration i.e. 1436 and $1425 \mathrm{~g} / \mathrm{h} / \mathrm{d}$ for both groups, respectively. The higher DMI depended in general on ration palatability, ingredients digestibility, besides the nutritive value of the ration. The higher DMI, in the present results may be due to the better palatability of treated (SCB and $\mathrm{Ccb}$ ) than the untreated ones and the better utilization by the host animals. Increased intake due to enzyme treated roughage, had been reported by several investigators (Oji and Mowat, 1979 and ElKamisi, 2008). On the other hand, the control groups (T1 untreated SCB and T6 untreated Ccb) showed the lower DMI, (1181 and $1140 \mathrm{~g} / \mathrm{h} / \mathrm{d})$, respectively. However, insignificant DMI was detected for both of the $\mathrm{SCB}$ and Ccb treated rations, as an overall means.

Digestibility coefficients of nutrients for both the two complete mixed rations i.e. SCB and Ccb rations, irrespective of different applicable treatments are shown in Table (5). Dry matter digestibility of of SCB rations ranged between $92.6 \%$ to $93.1 \%$ for T4 and T5, respectively. Dry matter digestibility of Ccb rations ranged between $92.92 \%$ and $93.63 \%$ for T8 and T9, respectively. DM digestibility of both the two treated roughages indicated significant differences $(\mathrm{P}<0.05)$ among different treated rations, however, DM digestibility of treated and untreated $\mathrm{Ccb}$ rations indicated higher $(\mathrm{P}<0.05)$ values in compare with the corresponding SCB rations i.e. $93.21 \%$ vs. $92.87 \%$, respectively. As for OM, CP and CF digestibility, data obtained indicated significant differences among different experimental rations, while T5 (treated SCB) and T10 (treated $\mathrm{Ccb}$ ) showed the highest $(\mathrm{p}<0.05)$ OM, CP \& CF values $(67.78$ and $66.67 \%)$, $(78.32$ and $77.33 \%$ ) and $(40.72$ and $35.20 \%)$, respectively. On the other side, the tow control rations (T1 and T6) recorded the lowest values among the different experimental rations (56.07 and 56.1\%), (26.34 and 33.19\%) and (16.2 and 13.24\%) for OM, CP \& CF, respectively. The higher CF digestibility of (T5 and T10) may interpretative the higher DMI of such rations, besides its relatively lower NDF and ADL, (Table 4). According to several authors, (Gado, 1997; Fouad et al., 1998 and Deraz and Ismail, 2001; Mahrous and Abou Ammou, 2005 and Gado, et al., 2009) CP and CF digestibility coefficients showed a wide range for low quality roughages treated by either $\mathrm{ZAD}$ or $\mathrm{ZADO}+$ urea treatments.

Data presented in Table (5) indicated, however insignificant difference between both the two treated and untreated SCB and the corresponding Ccb rations, irrespective of different biochemical treatments. The overall means of digestibility coefficients for both the two rations, regardles of different treatments were $62.78 \%$ vs. $63.04 \%$ OM, 61.08 vs. $60.96 \% \mathrm{CP}$ and $29.69 \%$ vs. $26.21 \% \mathrm{CF}$, respectively, indicating in general similar and insignificant digestibility coefficient values due to roughage source.

Results of EE and NFE showed in general, similar digestibility coefficient values for all experimental rations, however (T2 and T8) indicated insignificant higher values, with almost similar an overall means and insignificant values, regardless of treatments and roughage source . 
Table (5): Digestion coefficients and nutritive value of tested rations during the digestion trial.

\begin{tabular}{|c|c|c|c|c|c|c|c|c|c|c|c|c|}
\hline Item & $\begin{array}{l}\text { Control } \\
\text { SCB (T1) }\end{array}$ & (T2) & (T3) & (T4) & (T5) & $\begin{array}{l}\text { Overall } \\
\text { Mean }\end{array}$ & $\begin{array}{l}\text { Control } \\
\text { Ccb } \\
\text { (T6) }\end{array}$ & (T7) & (T8) & (T9) & (T10) & $\begin{array}{c}\text { Overall } \\
\text { Mean }\end{array}$ \\
\hline DM intake. & $\begin{array}{l}\mathbf{h} / \mathbf{d} \\
\mathbf{1 1 8 1} \\
\pm 31.72\end{array}$ & $\begin{array}{c}1338 \\
\pm 89.49\end{array}$ & $\underset{ \pm 85.71}{1415.75}$ & $\underset{t 103.30}{1189.75}$ & $\underset{ \pm 143.88}{1280.75}$ & 1281 & $\underset{ \pm 24.97}{1140.75}$ & $\underset{ \pm 64.89}{1182.5}$ & $\underset{ \pm 31.53}{1425.25}$ & $\underset{ \pm 118.80}{1333.5}$ & $\underset{ \pm 168.36}{1436.5}$ & 1303 \\
\hline $\begin{array}{c}\text { Digestibilii } \\
\text { DM }\end{array}$ & $\begin{array}{c}\text { Coeff. \% } \% \\
92.94^{1}\end{array}$ & $92.85^{1}$ & $92.89^{n}$ & $9 \underset{ \pm 0}{92.6^{1}}$ & $\underset{ \pm 0}{93.1^{e}}$ & $92.87^{b}$ & $\underset{ \pm 0}{93.23^{\mathrm{D}}}$ & $93.14^{\mathrm{d}}$ & $92.92^{9}$ & $93.63^{\mathrm{a}}$ & $93.17^{\mathrm{c}}$ & $93.21^{\mathrm{a}}$ \\
\hline OM & $\underset{ \pm 1.54}{56.07^{\mathrm{D}}}$ & $64.08^{\mathrm{a}}$ & ${ }_{ \pm 3.52}^{65.3^{\mathrm{a}}}$ & $\underset{ \pm 0.85}{60.69^{\mathrm{ab}}}$ & $\underset{ \pm 2.88^{a}}{67.78^{\mathrm{a}}}$ & 62.78 & $\underset{ \pm 1.23}{56.1^{\mathrm{D}}}$ & $\underset{ \pm 1.0}{63.02^{\mathrm{ab}}}$ & $\underset{ \pm 2.21}{66.44^{\mathrm{a}}}$ & $\underset{ \pm 3.04}{62.95^{\mathrm{ab}}}$ & $\underset{ \pm 2.58}{66.67^{\mathrm{a}}}$ & 63.04 \\
\hline CP & $\underset{ \pm 8.18}{26.34^{\mathrm{d}}}$ & $\underset{ \pm 2.10}{64.6^{\mathrm{bc}}}$ & $\underset{ \pm 2.31}{73.35^{\mathrm{ab}}}$ & $\underset{ \pm 2.0}{62.77^{\mathrm{bc}}}$ & $\underset{ \pm 2.54}{78.32^{\mathrm{a}}}$ & 61.08 & $\underset{ \pm 5.71}{33.19^{d}}$ & $\underset{ \pm 2.49}{62.15^{\mathrm{bc}}}$ & $\underset{ \pm 3.06}{73.3^{\mathrm{ab}}}$ & $\underset{+2.74}{58.83^{\mathrm{C}}}$ & $\underset{ \pm 1.53}{77.33^{\mathrm{a}}}$ & 60.96 \\
\hline CF & $\underset{ \pm 3.38}{16.2^{\text {cd }}}$ & $\underset{ \pm 5.96}{26.66^{\text {abcd }}}$ & $\underset{ \pm 6.93}{33.25^{\text {abc }}}$ & $31_{\mathrm{t7} .611}^{\mathrm{abc}}$ & $\underset{ \pm 5.86}{40.72^{\mathrm{a}}}$ & 29.69 & $\underset{+12.245}{13.24^{d}}$ & $\underset{\neq 2.37}{20.61^{\text {bcd }}}$ & $\underset{ \pm 4.68}{33.29 \mathrm{abc}}$ & $\begin{array}{l}28.71 \\
\pm 5.77\end{array}$ & $\underset{ \pm 4.61}{35.2^{\mathrm{ab}}}$ & 26.21 \\
\hline $\mathrm{EE}$ & $\underset{ \pm 2.76^{7}}{78.08^{\mathrm{D}}}$ & $\underset{ \pm 2.85}{83.09^{a b}}$ & $\underset{ \pm 3.48}{80.88^{a b}}$ & $\underset{ \pm 0.93}{76.93^{\mathrm{D}}}$ & $\underset{ \pm 1.56}{81.17^{\mathrm{ab}}}$ & 80.08 & $\underset{ \pm 1.13}{83.25^{a b}}$ & $\underset{ \pm 3.26}{81.95^{\mathrm{ab}}}$ & ${ }_{ \pm 2.53}^{88.6^{\mathrm{a}}}$ & $\underset{ \pm 5.47}{78.94^{\text {ab }}}$ & $\underset{ \pm 2.79}{80.85^{\mathrm{ab}}}$ & 82.72 \\
\hline NFE & $\underset{ \pm 1.29}{66.76}$ & $\underset{ \pm 2.15}{70.99}$ & $\underset{ \pm 3.26}{69.03}$ & $\underset{ \pm 1.43}{66.48}$ & $\begin{array}{l}69.2 \\
\pm 2.64\end{array}$ & 68.49 & $\underset{ \pm 1.01}{68.55}$ & $\begin{array}{c}71.36 \\
\pm 0.44\end{array}$ & $\underset{ \pm 1.61}{70.12}$ & $\begin{array}{l}70.0 \\
\pm 2.64\end{array}$ & $\begin{array}{l}68.76 \\
\pm 2.78\end{array}$ & 69.76 \\
\hline NDF & $24.9 \mathrm{gc}$ & $\underset{ \pm 7.42}{34.38^{\mathrm{abc}}}$ & $4=5.55^{\mathrm{a}}$ & $\begin{array}{l}30.15^{\mathrm{abc}} \\
\pm 1.40\end{array}$ & $\underset{ \pm 7.35}{22.12^{\mathrm{bc}}}$ & 31.02 & $\underset{ \pm 2.04}{20.61^{c}}$ & $\underset{\ddagger 2.13}{32.49^{\mathrm{abc}}}$ & $41.12^{\mathrm{a}}$ & $\underset{ \pm 5.23}{32.91^{\text {abc }}}$ & $37.67^{\mathrm{ab}}$ & 32.96 \\
\hline ADF & $\underset{ \pm 2.67}{6.99^{\mathrm{cd}}}$ & $\underset{ \pm 5.93}{23.83^{\mathrm{abc}}}$ & ${ }_{ \pm 10.30}^{35.26^{\mathrm{a}}}$ & $\begin{array}{l}7.7^{\mathrm{cd}} \\
\mathrm{t} 1.89\end{array}$ & $17.64_{ \pm 6.70}^{\text {bca }}$ & 18.29 & $\begin{array}{l}3.48^{\mathrm{d}} \\
\pm 1.40^{-1}\end{array}$ & $15.72^{\mathrm{bccd}}$ & $\underset{ \pm 4.90}{25.5 \mathrm{ab}^{\mathrm{ab}}}$ & $14.27_{ \pm 5.31}^{\text {bca }}$ & $14.11^{\mathrm{bccd}}$ & 14.63 \\
\hline ADL & $\underset{ \pm 6.20}{48.53^{b}}$ & ${ }_{ \pm 10.38}^{32.61^{b}}$ & $\underset{ \pm 15.58}{55.42^{\mathrm{b}}}$ & $\underset{ \pm 2.97}{48.48^{b}}$ & $\underset{ \pm 17.64}{88.84^{a}}$ & 54.78 & $\underset{ \pm 3.62}{45.17^{b}}$ & $\underset{ \pm 4.47}{46.75^{\mathrm{b}}}$ & $\begin{array}{l}64.6^{\text {ab }} \\
\pm 10.76\end{array}$ & $\underset{ \pm 12.06}{53.42^{b}}$ & $\underset{ \pm 11.09}{53.77^{b}}$ & 52.74 \\
\hline $\begin{array}{c}\text { Himi- } \\
\text { cellulose }\end{array}$ & $\underset{ \pm 2.39}{45.19^{\mathrm{bc}}}$ & $\underset{ \pm 3.60}{54.66^{\mathrm{ab}}}$ & $\underset{ \pm 4.50}{56.18^{\mathrm{a}}}$ & $\underset{ \pm 0.98}{49.8^{\mathrm{abc}}}$ & $\underset{ \pm 5.02}{47.19^{\mathrm{abc}}}$ & 50.59 & $\underset{ \pm 1.63}{41.43^{c}}$ & $\underset{ \pm 1.67}{49.67}$ & $\underset{ \pm 2.85}{56.11^{\mathrm{a}}}$ & $51.14_{ \pm 3.80}^{\mathrm{abc}}$ & $\begin{array}{l}56.8^{\mathrm{a}} \\
\pm 3.09\end{array}$ & 51.01 \\
\hline Cellulose & $\underset{ \pm 3.10}{25.41^{\mathrm{de}}}$ & $\underset{3.60}{43.45^{\mathrm{abc}}}$ & ${ }_{ \pm 4.84}^{53.87^{\mathrm{a}}}$ & $\begin{array}{l}30.64^{\mathrm{cde}} \\
\pm 1.42\end{array}$ & $\underset{ \pm 7.78}{17.85^{\mathrm{e}}}$ & 34.25 & $\underset{t 1.95}{19.46^{e}}$ & $\underset{\text { t1.92 }}{37.52^{\mathrm{bcd}}}$ & $49.22^{\mathrm{ab}}$ & $\underset{ \pm 44.97}{35.86^{\text {bcd }}}$ & $\underset{ \pm 4.64}{36.47^{\mathrm{bcd}}}$ & 35.71 \\
\hline $\begin{array}{c}\text { Nutritive V } \\
\text { TDN }\end{array}$ & $\begin{array}{l}5.83_{ \pm 1.14} \\
53.83^{c}\end{array}$ & $62.59^{\mathrm{ab}}$ & $63.12^{\mathrm{ab}}$ & $58_{ \pm .1 .29}^{\text {abc }}$ & $\underset{ \pm 2.68}{65.28^{\mathrm{a}}}$ & 60.75 & $56.81^{\mathrm{Dc}}$ & $61.64^{\mathrm{ab}}$ & $66.32^{\mathrm{a}}$ & $62.15^{\mathrm{ab}}$ & $65.96^{\mathrm{a}}$ & 62.57 \\
\hline DCP & ${ }_{ \pm 1.28}^{3.65^{c}}$ & $\underset{ \pm 0.30}{9.36^{\mathrm{ab}}}$ & $\underset{ \pm 3.23}{11.77^{\mathrm{ab}}}$ & $\underset{ \pm 1.27}{9.11^{\mathrm{abc}}}$ & ${ }_{ \pm 2.64}^{13.5^{\mathrm{a}}}$ & 9.48 & $3.66^{\mathrm{bc}}$ & $\underset{ \pm 1.84}{8.75^{\mathrm{ab}}}$ & $\underset{ \pm 2.11}{11.91^{\mathrm{a}}}$ & $\begin{array}{c}8.73^{\mathrm{ab}} \\
\pm 2.93\end{array}$ & $\underset{ \pm 2.34}{13.33^{\mathrm{a}}}$ & 9.28 \\
\hline SE & $\underset{ \pm 0.31}{49.95^{d}}$ & $\underset{ \pm 2.31}{58.92^{\mathrm{c}}}$ & $\underset{ \pm 0.37}{58.52^{\mathrm{b}}}$ & $\underset{ \pm 0.29}{54.53^{\mathrm{c}}}$ & $\underset{ \pm 0.43}{60.81^{\mathrm{a}}}$ & 56.55 & $\underset{ \pm 0.63}{52.59^{a}}$ & ${ }_{ \pm 0.50}^{57.10^{c}}$ & $\underset{ \pm 0.49}{61.72^{\mathrm{b}}}$ & $\underset{ \pm 0.40}{57.75^{c}}$ & $\underset{t 0.26}{61.54^{\mathrm{a}}}$ & 58.16 \\
\hline $\mathrm{C} / \mathrm{P}$ ratio & $14.95^{\mathrm{a}}$ & $\underset{0.67^{\mathrm{D}}}{6.05}$ & $\underset{00.13}{5.35^{\mathrm{D}}}$ & $\underset{\substack{0.47^{\mathrm{D}} \\
\text { to. }}}{ }$ & $4.83^{\mathrm{D}}$ & 7.65 & $\underset{ \pm 2.70^{a}}{16.7 a^{a}}$ & $\underset{7.07^{\mathrm{D}}}{70.22}$ & 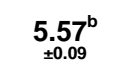 & $\underset{7.0 .11^{\mathrm{D}}}{7.06}$ & $\underbrace{4.94^{\mathrm{D}}}_{ \pm 0.12}$ & 8.28 \\
\hline
\end{tabular}

$a, b, c, d, e, f, g, h, i \& j$ different small letters in the same row indicated significant difference $(P<0.05)$

In general, it can be concluded that all species of cellulolytic bacteria as biological treatments, had a significant positive effect on increasing crude fiber digestibility (CF) (from $16.2 \%$ and $13.24 \%$ to $29.69 \%$ and $26.21 \%$ as an overall mean of treated SCB and Ccb ) and increasing crude protein digestibility (CP) values( from $26.34 \%$ and $33.19 \%$ to $61.08 \%$ and $60.96 \%$, as an overall mean of treated SCB and Ccb ) respectively.

Digestibility data obtained in the present study are within those obtained in many previous studies (Newbold et al., 1995; Putnam et al., 1997 and El Badawi et al., 1998).

Digestibility of NDF for T3 of SCB ration and that of T8 Ccb were significantly higher $(\mathrm{P}<0.05)$ than those of their corresponding control groups. However, insignificant difference was detected between the overall mean of both the two complete mixed rations i.e. $31.02 \%$ and $32.96 \%$, respectively. ADF digestibility for $\mathrm{T} 3$, of SCB and T8 of Ccb ration were significantly higher $(\mathrm{P}<0.05)$ than their corresponding control ones; with an overall means of $18.29 \%$ and $14.63 \%$, indicating higher $(\mathrm{P}<0.05)$ ADF for the SCB rations. Values of cellulose digestibility coefficient of untreated SCB was $25.41 \%$ while, that of (T3) treated SCB was $(\mathrm{P}<0.05)$ higher by $53.87 \%$, the other treatments fall in between $(17.85$ to $53.87 \%)$. Values of cellulose digestibility coefficient of untreated $\mathrm{Ccb}$ (the control) was $19.46 \%$, which differed $(\mathrm{p}<0.05)$ from that of T8 (49.23\%); the other treatments fall in between (19.46 to 49.23\%). However, similar overall mean and insignificant values were recorded for both the two complete mixed rations i.e. $34.25 \%$ and $35.71 \%$ cellulose, respectively. 


\section{Salama et al.}

The higher $(\mathrm{P}<0.05)$ hemicellulose digestibility values of SCB and Ccb rations were $(56.18$ and $56.80 \%)$ for T3 and T10, respectively, while the lowest values were recorded for the controls (untreated SCB and Ccb rations) i.e. 45.12 and $41.43 \%$ respectively, and almost similar insignificant hemicellulose values for the overall means of both the two rations i.e. $50.69 \%$ and $51.01 \%$, respectively, irrespective of the biochemical treatments and source of roughage. Similar results were obtained by Mohamed (2001) who reported that, NDF, ADF, ADL, hemicellulose and cellulose digestibilities were increased $(\mathrm{P}<0.05)$, when SCB was treated with fungi and acid plus urea. Abd-El-Aziz and Ismail (2001); Bassuny et al., (2003) and (2005) reported that $\mathrm{ZAD}$ and $\mathrm{ZAD}+$ urea treatments showed a significant positive effect of loosening lignucelluloletic bonds and solubilize some of the hemicellulose content of treated roughages .

Nutritive value of the complete mixed rations in terms of TDN, showed higher significant values $(65.28$ and $66.32 \%$ ) with T5 and T8, respectively and both the two rations indicated significantly higher values $(\mathrm{P}<0.05)$ than the two control groups ( $\mathrm{T} 1$ and $\mathrm{T} 6)$. However, different experimental rations indicated higher TDN values in compare with the control group. Also, DCP showed higher values for T3 and T5 (SCB) and $\mathrm{T} 8$ and $\mathrm{T} 10$ treated $\mathrm{Ccb}$, respectively and were significantly higher $(\mathrm{P}<0.05)$ than the two control rations $(\mathrm{T} 1$ and T6) and surpassed $(\mathrm{P}<0.05)$ the other treated rations.

However, the nutritive values for different (treated and untreated complete mixed rations), irrespective of biochemical treatments, indicated insignificant and almost similar TDN (60.75\% and 62.57\% TDN) and (9.48\% and 9.28\% DCP), for SCB and Ccb rations, respectively. Similar results were reported by Gado et al., (2009).

The similar trend was also observed with SE values, as it was noticed significant differences among different experimental rations in favor of T5 and T10, but lower insignificant SE values with untreated SCB and $\mathrm{Ccb}$ rations ( $49.95 \%$ and $52.59 \%$ ), respectively . However, both the two complete mixed rations indicated insignificant SE values (56.55\% and 58.16\%), respectively.

On the light of the present results, it was concluded that, biochemical treatments led to improve $(\mathrm{P}<0.05)$ nutrients digestibility for both the two treated roughages and their fiber fractions and enriched their nutritive values in terms of DCP and caloric values, however relative responses were detected between both the two treated roughages for different applicable treatments, which is mainly related to the chemical and structural composition of both the two raw materials and its lignification nature.

\section{CONCLUSION}

On the light of the present results, it could be concluded that, treating poor quality roughages (SCB \& $\mathrm{Ccb}$ ) with the natural biological additives probiotics (ZAD \& ZADO compounds) led to improve roughage chemical composition, digestibility of their nutrients, roughage palatability and in turn might contribute to the marginal field of available roughage resources.

\section{REFERENCES}

AOAC (2005). Official Methods of Analysis of AOAC International, 18th ed. AOAC, Gaithersburg, MD, USA

Abd El-Aziz, A. A. and H. Ismail (2001). Evaluation of rice straw treated with urea solution or fungus (P. ostreatus) for sheep. J. Agric., Sci., Mansoura Univ. 26: 6694.

Abd El-Aziz, G. M. ; Y. E. El-Talty and M. A. Ali (1997). Biological treatments of straws in animal nutrition. Egyptian J.Nutr. and Feeds , Nov . (Special Issue): 225-234.

Bakshi , M. P. S. and P. N. Langar (1985). Utilization of Agaricus Bisporus harvested spent wheat straw in buffaloes . Indian J . Anim. Sci., 55 (12): 1060-1063.

Balch, C.C. (1976). The potential of poor quality agricultural roughages for animal feeding. F.A. O. Animal Production and Health paper NO. 4. New Feed Resources, Food and Agriculture Organization of United Nation, Rome, 1977. 
Barnes, A. C. (1980). The sugar cane. The world crop series. Leonard Hill books second edition.

Bassuny, S. M., A. A. Abd El-Aziz, M. F. El-Sayis and M. A. Abdulla (2003). Fibrous crop by-products as feed. 2. Effect of chemical and biochemical treatments on feed intake, nutritive values and some ruminal and blood constituents. Egyptian J. Nutrition and Feeds (2003) 6 (Special Issue): 901-912.

Bassuny, S.M., A.A. Abdel-Aziz, H.J. Abdel-Fattah and M.Y.S. Abdel-Aziz (2005) . Fibrous croup byproducts as feed . 4- Effect of biological treatments for rice straw and bean straw on chemical composition, digestibility and some ruminal and blood constituents of sheep. Egypt .J.Nutrition and Feeds 8(1) (Special Issue): 541 -554.

Beauchemin, K., D. Colombatto, D.P. Morgavi and W.Z. Yang (2003). Use of exogenous fibrolytic enzymes to improve feed utilization by ruminants. J. Anim. Sci. 81: 37-47.

Colombatto, D.F.L., M.K. Mould, D.P. Bhat, K.A. Morgavi and K. Beauchemin (2003) . Influence of fibrolytic enzymes on the hydrolysis and fermentation of pure cellulose and xylan by mixed ruminal microorganisms in vitro . J. Anim. Sci. 81: 1040-1050.

Deraz, T.A. and H. Ismail (2001). Cotton stalks treated with white-rot fungi for feeding sheep . Egyptian J. Nutrition and Feeds 4(Special Issue): 423-434.

Dhanda, S., V. K. Kakkar, H. S. Garcha and G. S. Makkar (1994). Biological treatment of the paddy straw and its evaluation through ruminant feeding . Indian J. Anim. Nutr., 11(2) : 37-79.

Duncan, C. B. (1955). Multiple range and Multiple F-test Biometrics. (11): 1- 42.

El-Ashry, M. A., H.M. El-Sayed, M. Fadel, H.M. Metwally and M. M. Khorshed (2002). Effect of chemical and biological treatments of some crop residues and their nutritive value: 2. Effect of biological treatments on chemical composition and in-vitro disappearance. Egyptian J. Nutrition and Feeds, 5: 4354 .

El Badawi, A. Y., H. M. Gado and M. A. Tawila (1998). Influence of dietary yeast culture on the lactation performance of goats. Arab Univ. J. Agric.Sci., Ain Shams., Cairo, 6:111.

El-shazly, K.; A. R. Abu Akkada and M. A. Naga (1963). The use of the in vitro fermentation technique to estimate the digestible energy content of some Egyptian forages. J. agric. Sci., 61:109.

El-Kamisi, M. M. B. (2008). Nutritive evaluation of biologically and chemically treated rice straw in complete mixed ration in fattening local male lambs. M. Sc. Thesis, Fac. of Agric., Al-Azhar UnivCairo.

EL-Khimsawy, K. A. (1990). The second scientific symposium on animal, poultry and fish nutrition.26-27 Dec. 1990, Mansoura Univ.

Fouad, R. T., T. A. Deraz and S. A. Ismail (1998). Biological vs urea treatment of roughages for sheep. J. Agric. Sci. Mansoura Univ., 23 (1): 103- 116.

Gado, H. (1997). Effect of enzymatic treatments for poor quality roughage on fiber digestibility and nitrogen metabolism in Baladi goats. Egyptian. J. Nutrition and feeds, 1: (Special Issue), 49-56.

Gado, H., S. A. Nasr, B. K . Mohamed and A. A. Mahrous (2006). Effect of biological treatment on the nutritive value of rice straw .Egypt .J.Nutri and Feeds. 9(2):207-219.

Gado, H.M.; Salem, A.Z.M.; Robinson, P.H., Hassan, M., (2009). Influence of exogenous enzymes on nutrient digestibility, extent of ruminal fermentation as well as milk production and composition in dairy cows. Anim. Feed Sci. Technol. 154, 36-46.

Gado, H.M.; Salem, A.Z.M.; Camacho, L.M.; Elghandour M.M.Y.; Salazar, M.C., (2013). Influence of Exogenous Enzymes on In Vitro Ruminal Degradation of Ensiled Rice Straw with DDGS. Animal Nutrition and Feed Technology (2013) 13: 569-574.

Goering, H. K. and P. J. Van Soest (1982) . Forage fiber analysis, apparatus, reagents, Procedures and some applications. Agriculture handbook No. 379, USDAARS, Washington.

Khorshed, M.M. (2000). Different treatments for improving nutitional quality of some crop residues used in ruminant nutrition. Ph.D. Thesis . Fac. Of Agric. Ain Shams University. 


\section{Salama et al.}

Mahrous, A. A. and Faten F. Abou Ammou (2005) . Effect of biological treatments for rice straw on the productive performance of sheep. Egyptian J. Nutrition and feeds. 8(1) Special issue: 529 - 540.

Ministry of Agriculture (1996). Agricultural Economics. Bull. Central Dept. of Agric., Mini. Eco. Cairo. Egypt. Part 1 Publ. By Agric. Res. Center.

Ministry of Agriculture (2000). Economic Affairs Sector Agriculture, Statistics (1): Nov. 2000, Egypt.

Mohamed, I. M. E. (2001). Effect of mechanical, chemical and /or biological treatments of roughage on ruminal activity. Ph. D. Thesis. Faculty of Agriculture, Cairo University.

Newbold, C. J., R. J. Wallace, X.B. Chen and F. M. Mclntosh (1995). Different strains of Saccharomyces cervisiae differ in their effects on ruminal bacterial numbers in viro and in sheep.J.Anim.Sci.73:18111818.

NRC (1989). Nutrient Requirements of Dairy Cattle, 6th Rev. ed . National Research Council. Acad. Sci., Washington, D. C.

Oji, U. I. and D. N. Mowat (1979). Nutritional value of thermo ammoniated and steam treated maize stover. 1. Intake, digestibility and nitrogen retention. Anim. Feed Technol. (4) 177-186.

Putnam, D. E., C. G. Schwab, M. T. Socha, N. L. Whitehouse, N. A. Kierstead and B. D. Garthwaite (1997). Effect of yeast culture in the diets of early lactation dairy cows on ruminal fermentation and passage of nitrogen fractions and amino acids to the small intestine. J. Dairy Sci (80). $374-384$

Rmadan, F. (2007) . Biological treatment of agriculture by products and their effect on lambs performance M.Sc. Thesis, Anim. Prod. Dept., Fac. of Agric., Ain-Shams Univ.

SAS (1996) . Statistical Analysis System. User's Guide : Version 6, $4^{\text {th }}$ Ed., Vol.2, Cary NC : SAS Institute INC. 
إستخدام بعض المعاملات البيوكيميائية فى تحسين القيمة الغذائية لبعض مواد العلف الخثنة (دراسات معملية

رضا سلامه محمد ، أحمد عبدالغنى عوض و شوقى مصباح فودة

قسم الإنتاج الحيوانس ـ كلية الزراعة بالقاهرة - جامعة الأزهر ـ مدينة نصر - القاهرة ـ مصر.

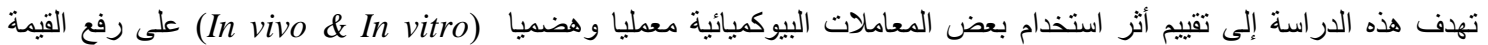

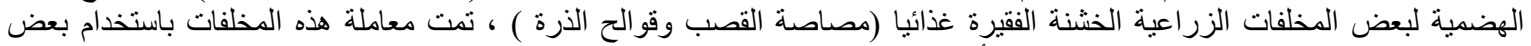
المركبات الإنزيمية الحيوية Probiotics (زاد و أو زادو) ضمن 10 معاملات بيوكيميائية بمعدل 5 معاملات لكل مخلف على النحو النيات النالى :

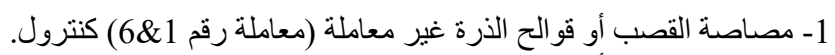

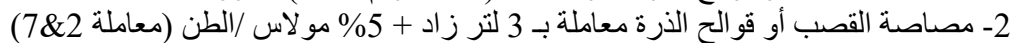

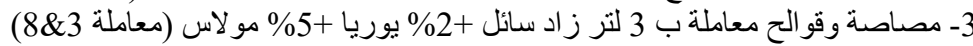

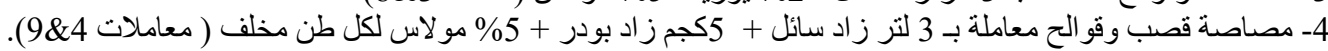

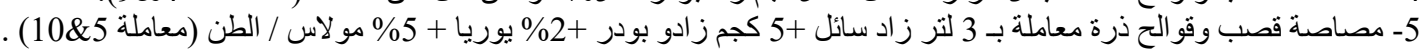

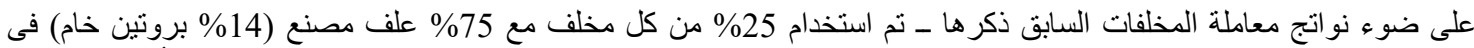

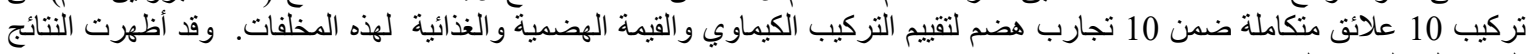

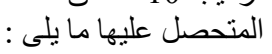

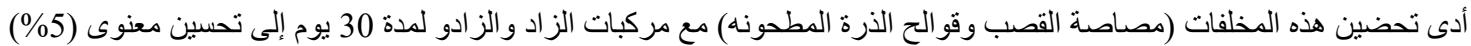

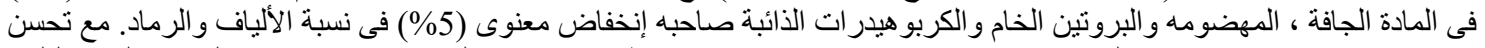

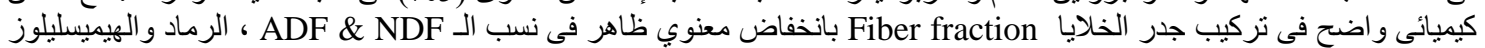
مع الأخذ فى الإعتبار وجود تباين معنوي بين كل من المخلفين فى مدى استجابتها للمعاملات البيو كيمانياتئية.

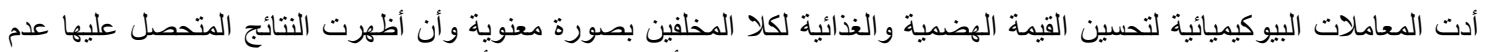

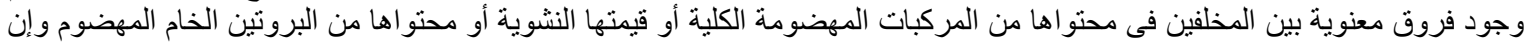

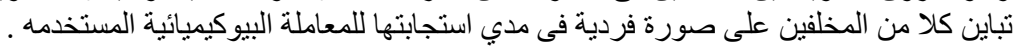

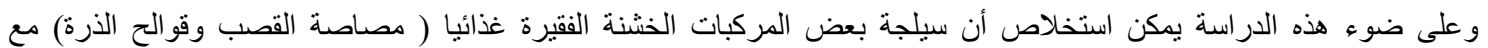

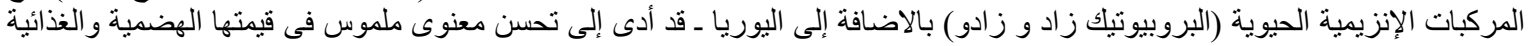

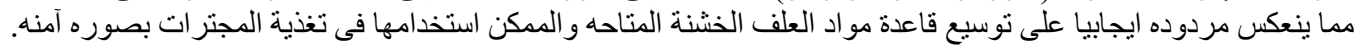

